malnych warunków rozwoju roślin] nie powinno być żadnym nadmiarem ani żadnym brakiem, i to zarówno co do ilości, jak i jakości dla roślin". Wielokrotnie wraca do znaczenia wody dla roślin: „,wody, które są slone albo alkaliczne, albo kwaśne, albo zawierające inny smak, ani nie żywią roślin, ani ich nie rodzą, z wyjątkiem wypadków, kiedy takie wody, jak woda morska, mogą wydać roślinę o pokrewnym im smaku".

Między organizmami występują różnego rodzaju interakcje, na przykład między roślinami i ptakami: „Natura powoduje występowanie wielu takich wypadków u roślin i zwierząt, że jedno drugiemu jest pomocne ze względu na zachowanie i powstawanie [...] jak u zwierząt zdarzają się wypadki wzajemnej zagłady i zachowania, i to na dalszy ciąg życia i na kontynuowanie procesu powstawania - tak nic nie przeszkadza, żeby to samo prawo rozciągało się w swoim zakresie od zwierząt do roślin" (II 10,18).

W swych pracach Teofrast podaje różnego rodzaju zagrożenia życia, które sam obserwowal lub które były podawane przez podróżników: „w Milecie, kiedy rośliny są w okresie kwitnienia, rodzą się dwojakiego rodzaju gąsienice, $\mathrm{z}$ których jedne pożerają liście, a drugie kwiaty [...] a jakby wydostaje się tu z morza jakaś mgła bez wiatru, która kiedy spadnie na kwiaty, wypala je". Na podstawie przekazu podróżników podaje, że w Libii pojawiają się „,smolowate” i gęste deszcze. Ważny jest także jego podział zagrożeń na pochodzące z gleby, ze zmian klimatu i z działań człowieka.

Jaki jest wkład Teofrasta w rozwój nauki, w tym problematyki ekologicznej? Wskazał on na naukowe środki poznawania przyrody (obserwacja, eksperyment), tym samym przyczynił się do budowania racjonalnego obrazu przyrody. Ukazal rolę przyczyn naturalnych, rolę praw naturalnych w odkrywaniu przyrody. Dalsze jego osiągnięcie to unifikacja danych ukazanych w obserwacji zjawisk (woda, powietrze, ziemia to tylko przykłady tego zabiegu). Zapoczątkował przez wskazanie na relację organizm - środowisko budowanie tematyki ekologicznej.

Ks. Stanisław Zięba - Lublin, KUL

\title{
Andrzej FLIS - Beata KOWALSKA, Zapomniani bracia. Ginqcy świat chrześcijan Bliskiego Wschodu, Kraków 2003, Wydawnictwo WAM, ss. 208.
}

Jest to duży $(30 \times 24 \mathrm{~cm}$ ) piękny album z obszernym wstępem (ss. 1-47) i 152 kolorowymi zdjęciami zaopatrzonymi rozległymi objaśniającymi podpisami, ilustrującymi historycznie obecny stan architektury i życia chrześcijańskich, glównie syryjskich, wspólnot na Bliskim Wschodzie. Książka ta jest owocem naukowej wyprawy Zakładu Porównawczych Studiów Cywilizacji Instytutu Socjologii Uniwersytetu Jagiellońskiego, prowadzącej w latach 1998-2000 badania na tere- 
nie Turcji, Syrii, Libanu, Jordanii, Iraku, Iranu i Izraela, dokumentującej w nich wymierające najstarsze wspólnoty chrześcijańskie. Wspólnoty te bowiem, wywodzące się najczęściej od apostołów Piotra, Pawła, Jakuba i Tomasza, pielęgnujące poprzez wieki swoje tradycje, wiarę i język aramejski, podobne do tych, w jakich dwa tysiące lat temu przekazał swoją naukę Jezus Chrystus, wskutek dyskryminacji i represji ze strony otaczającego je świata muzułmańskiego, powoli zanikają lub emigrują do Europy albo Stanów Zjednoczonych. Oprócz celów ściśle naukowych album chce w sposób naoczny i atrakcyjny popularyzować wicdzę o tych wymierających zapomnianych braciach.

We wspomnianym wstępie pt. „Z dziejów chrześcijaństwa na Bliskim Wschodzie", podzielonym na cztery rozdziały, zaopatrzone w odpowiadające ich treści mapy, przypomniana jest ogólna historia tych wspólnot, udokumentowana nierzadko źródłami patrystycznymi. W pierwszym $\mathrm{z}$ nich zatytułowanym „Bliski Wschód kolebką chrześcijaństwa” (ss. 10-14) jest mowa o jego szybkim rozpowszechnianiu się w Azji Mniejszej i basenie Morza Sródziemnego, do czego przyczyniły się dwie zasadnicze przyczyny: atrakcyjność jego nauki moralnej oraz infrastruktura Cesarstwa Rzymskiego (drogi i wspólny grecki język); w jego łonie pojawiły się trzy odrębne nurty, związane $z$ trzema dominującymi tradycjami kulturowymi: chrześcijaństwo orientalne - najbliższe judaizmowi, chrześcijaństwo greckie, oraz chrześcijaństwo łacińskie - najmłodsze i najodleglejsze od apostolskich wzorów.

W rozdziale drugim: „Między Antiochią i Edessą” (ss. 14-27) podzielonym na cztery kolejne podrozdziały (Orientalne korzenie Kościołów syryjskich, Antiochia - pierwszą stolicą Piotrową, Edessa - Ateny Wschodu, Spory chrystologiczne) przypomniana jest dalsza chrystianizacja Bliskiego Wschodu w aramejskim języku Jezusa i mocnym wpływie judaizmu we wschodniej Syrii i Mezopotamii oraz greckim na terenach zachodnich, ogniskująca się, według autorów wstępu, wokół dwóch stolic - Edessy i Antiochii, którym poświęcimy nieco więcej uwagi.

Pierwsza z nich, znajdująca się pod dużym wpływem judaizmu, której biskupi posługiwali się aramejskim i przetlumaczoną na ten język Biblią hebrajską, interpretowaną według zasad egzegezy żydowskiej, pełna $z$ jednej strony niechęci do spekulacji greckich, a z drugiej skłonności do mistycyzmu i skrajnej ascezy (enkratyzm, gnostycyzm), będąc początkowo (lata 136 prz. Chr. -216 po Chr.) stolicą niewielkiego państwa Osroena pod panowaniem dynastii Abgarów, leżącego między imperium perskim a Cesarstwem Rzymskim, stała się dla semickich chrześcijan Wschodu ważnym centrum kulturowym, które autorzy wstępu nazywają „Atenami Wschodu” (s. 21), analogicznym do Antiochii, Konstantynopola i Aleksandrii; również potem, gdy wcielona do Cesarstwa Rzymskiego uległa hellenizacji i w dużym stopniu utraciła swój semicki charakter, nadal pozostała ważnym centrum kulturowym Wschodu, będąc od $363 \mathrm{r}$. miejscem słynnej szkoły teologicznej, nazywanej „Szkołą Persów”, w której 
obok teologii i filozofii greckiej studiowano matematykę i nauki przyrodnicze, oraz prowadzono szeroką działalność translatorską, mimo chwilowego jej zamknięcia w 489 r. z powodu oskarżenia o szerzenie herezji nestorianizmu, stała się potem faktycznie nie tylko centrum teologii nestoriańskiej, ale także instytucją edukacyjną z ułożonym w 496 r. przez nestoriańskiego biskupa Nisibis Barsaumę specjalnego statutu akademii (o tej szkole i tekst jej statutów w przekładzie Cz. Mazura zob. H.W. Pigulewska, Kultura syryjska we wczesnym średniowieczu, Warszawa 1989, 93-120). Mimo represji nie osłabła działalność translatorska uczonych tego ośrodka, która osiągnęła swoje apogeum w VII wieku, ocalając od zagłady znaczną część dziedzictwa klasycznego Grecji: dzieła greckie tłumaczone w Edessie, Nisibis i okolicznych klasztorach na aramejski i syryjski, po zdobyciu Syrii przez muzułmanów przekładane były na język arabski i w średniowieczu docierały do Europy (o tej syryjskiej działalności translatorskiej dzieł greckich zob. Pigulewska, jw., s. 159-204).

Przy charakteryzowaniu zaś Antiochii, Autorzy wstępu starali się wykazać przede wszystkim Piotrową genezę jej biskupstwa (szkoda, że bez wskazania konkretnych miejsc w źródłach), przytaczając na jej uzasadnienie najstarsze wzmianki o tym: $z$ Listu św. Pawła do Galatów $(2,11)$, a z patrystycznych Orygenesa wspominającego „Ignacego, trzeciego po Piotrze biskupa Antiochii" (In Lucam hom. 6, 4, PSP 36, 45), Euzebiusza z Cezarei mówiącego o „Ignacym..., który jako drugi następca Piotra zasiadał na biskupstwie antiocheńskim" (HE III 36, 2, POK 3, 135), św. Hieronima mówiącego wprost, że Piotr był pierwszym biskupem Antiochii, oraz List synodalny I Soboru Konstantynopolitańskiego (381) do papieża Damazego, gdzie Antiochia nazwana jest Kościołem apostolskim (Epistula Concilii Constantinopolitani ad Damasum 8, ŹMT 24, 85: „Dla najstarszego i prawdziwie apostolskiego Kościoła w Antiochii Syryjskiej"). To w tym mieście miała być celebrowana jedna $\mathrm{z}$ najstarszych $\mathrm{w}$ chrześcijaństwie liturgia antiocheńska, zwana niekiedy obrządkiem św. Jakuba, który, jak mówi tradycja apokryficzna, miał ją ułożyć w Jerozolimie według nadprzyrodzonych wskazówek $\mathrm{z}$ nieba, ale przeniesiona później do Syrii zastąpiła ówczesny obrządek antiocheński. To z tego miasta wyruszał na swe podróże apostolskie św. Paweł, to w tym mieście w połowie IV wieku powstała antiocheńska szkoła teologiczna, promująca literalną metodę interpretacji Pisma Świętego. Kres jedności tego rozwijającego się na Bliskim Wschodzie chrześcijaństwa położyły spory chrystologiczne w V wieku, które $z$ jednej strony rozdzieliły chrześcijaństwo syryjskie na dwa wrogie obozy: nestoriański i monofizycki, a $z$ drugiej oderwały je od kultury Zachodu, tworząc po Soborze Efeskim (431) i Chalcedońskim (451) wojujące ze sobą frakcje i glębokie podziały istniejące do dnia dzisiejszego. Prześladowani zwolennicy Nestoriusza udali się na wygnanie do Persji tworząc tam odrębny Kościół, który oddzielił się formalnie od patriarchatu antiocheńskiego w 484 r., stając się po kilku wiekach jedną $\mathrm{z}$ największych wspólnot chrześcijańskich na świecie. 
Trzeci rozdział zatytułowany „Syryjskie wspólnoty chrześcijańskie (ss. 2839) omawia już konkretne syryjskie Kościoły powstałe po Soborze Chalcedońskim (451). Są zaś nimi: najpierw wywodzący się z monofizytyzmu „Jakobici Syryjski Kościół Ortodoksyjny” (ss. 28-50), zorganizowany przez świętego ascetę i niestrudzonego misjonarza biskupa Edessy Jakuba Baradaja, który mimo prześladowań bizantyńskich był w rozkwicie aż do XV wieku (o jego historii i aktualnym stanie zob. T. Wyszomirski, Kościót syryjski, „Novum” 1980, nr 1, 147-154; B. Modzelewska, EK VII 685-689); autorzy wstępu omawiają też przy nim krótko działających w Indiach „Chrześcijan św. Tomasza” (s. 50). Potem omówieni są żyjący we wschodniej Syrii i w Persji „Nestorianie Asyryjski Kościól Wschodni" (ss. 30-33; zob. T. Wyszomirski, Kościót Asyryjski, „Novum” 1979, nr 11, 200-206), następnie „Chrześcijańskie misje na Wschodzie" (ss. 33-38) od III do XV wieku, przy których przytoczone są m.in. Edykt cesarza Tai-Tsunga (s. 36) i krótka charakterystyka nestorian w Tybecie (s. 38), a na końcu „Kościól Chaldejski” (ss. 38-39), oznaczający tę cześć wspólnoty nestoriańskiej, która przyjęła obrządek katolicki i zawarła unię z Rzymem za papieża Juliusza III (o tym Kościele zob. K. Szegda, EK III 56-57).

Ostatni wreszcie rozdzial wstępu pt. „Brzemię ostatnich wieków” (ss. 4047) opisuje losy wyżej omówionych Kościołów w ostatnich pięciu wiekach aż po dzień dzisiejszy, omawiając przy tym zagrażający im ciągle wpływ Zachodu, ich wieloletnią eksterminację przez świat muzułmański oraz ich ekumeniczne relacje z Kościolem katolickim.

Drugą część albumu, zajmującą 3/4 jego objętości, zatytułowaną „Wśród najstarszych wspólnot chrześcijańskich", stanowią zdjęcia z bardzo rozbudowanym i ciekawie ujętym słownym komentarzem historycznym, dotyczące kolejno prezentowanych następujących krajów: Turcji, Syrii, Libanu, Jordanii, Ira$\mathrm{ku}$, Iranu i Izraela. Zdjęcia te ukazują krajobrazy i charakterystyczne postacie omówionych we wstępie Kościołów we współczesnych strojach oraz ich niektóre reprezentatywne zabytkowe budowle $\mathrm{w}$ aktualnym stanie, $\mathrm{z}$ dodaną konturową mapką odnośnego kraju z zaznaczeniem na niej omawianej miejscowości. Ze wszystkich wyżej wymienionych państw najwięcej zdjęć poświęcono Irakowi, Turcji i Syrii.

W Turcji (ss. 50-83) najpierw udokumentowano w ten sposób Konstantynopol (ss. 50-55), a następnie zamieszkany od dwóch tysięcy lat przez chrześcijan południowy skrawek tureckiego Kurdystanu zwany Tur Abdinem (ss. 5683), na pograniczu dawnej Persji i Bizancjum, podobny w swym znaczeniu do góry Athos w greckim prawosławiu. To na tym terenie znajduje się wiele znanych w chrześcijaństwie miejscowości, świątyń i klasztorów, a wśród nich aktualne zdjęcia Nisibis (Nusajbin) i Edessy (Sanliurfa, ss. 79-83). Niewiele mniej zdjęć poświęcili nasi Autorzy Syrii (ss. 84-111), w której udokumentowali najpierw miejsce pobytu i kultu św. Szymona Słupnika w Qal' at Simaan 
(ss. 84-89), potem Damaszek z katedrą św. Jana Chrzciciela nad jego grobem i z oknem w bramie św. Pawła (ss. 90-93), potem w północno-wschodniej Syrii El-Jasir („Chrześcijański Raj”) z jego świątyniami i sanktuariami, w którym żyje ok. 150 tys. chrześcijan różnych Kościołów (ss. 95-108), nie zapominając przy tym o malej wiosce w południowo-wschodniej Syrii - Maalula (s. 107) $z$ aramejskim językiem Jezusa, w której można się spotkać $z$ dużą sympatią dla Polaków, bo podczas II wojny światowej odwiedzil ją generał Anders obdarzając mnichów klasztoru św. Sarkisa i św. Bakusa dwoma ikonami. O wiele mniej miejsca poświęcili nasi Autorzy Libanowi (ss. 112-119), w którym żyje 14 wspólnot chrześcijańskich $z$ najliczniejszymi maronitami i jakobitami (tylko cedry i kościoły w Byblos) oraz Jordanii (ss. 120-125) z bardzo nielicznymi chrześcijanami (zaledwie 5\%), zamieszkałej głównie przez Arabów uważających sie za potomków Izmaela (tylko wykuty w III wieku w skale klasztor w Petrze oraz góra Nebo z klasztorem zawierającym grób Mojżesza).

Najwięcej zdjęć poświecili Autorzy albumu, jak wspominaliśmy, Irakowi (ss. 126-165), w którym na 22 miliony ludności aż 900 tys. stanowią chrześcijanie, zwracając uwagę nie tylko na architekturę, ale i na różne chrześcijańskie ugrupowania. Dokumentowali tu więc najpierw Ktezyfon, który jest m.in. stolicą Chaldejskiego Patriarchatu Babilonii (Chaldejczycy stanowią największą wspólnotę chrześcijańską w Iraku, ok. 200 tys.), potem chrześcijańskie pomniki Bagdadu, następnie leżący na północy Mosul - kolebkę irackiego chrześcijaństwa $z$ kościołem jego ewangelizatora św. Tomasza, potem zdjęcia wzniesionego 2100 lat prz. Chr. zikkuratu w Ur (s. 153), gdzie urodził się i skąd wyszedł Abraham, a także miejsce biblijnego raju w okolicach Al Qurna w południowo-wschodnim Iraku (s. 154). Z ugrupowań zaś najwięcej miejsca poświęcili najpierw ciekawej żyjącej w Bashiqa 11-tysięcznej wspólnocie jezydów (s. 146-149), uważających się za naród wybrany, pochodzący od pary bliźniąt urodzonych w dzbanie z nasienia Adama bez udziału Ewy, posiadajacych wlasną dogmatykę i ascezę; a potem mandejczykom (s. 154-165), nazywanym „,chrześcijanami św. Jana”, z opisem ich sakramentalnej liturgii odprawianej nad Tygrysem i w Bagdadzie.

Mniej architekturze, a więcej zwyczajom i strojom poświęcili Autorzy albumu Iranowi (ss. 166-189), w którym są tylko slady chrześcijaństwa, głównie na jego północy wśród Kurdów; tutaj, zwłaszcza w Urmii, miał według tradycji działać św. Tadeusz, i tędy mieli przejeżdżać Trzej Mędrcy. Nasi Autorzy zauważyli natomiast pewne polonicum w leżącym w centrum Iranu mieście Isfahan, gdzie ormiański Kościół opiekuje się znajdującymi się w nim polskimi grobami. W podpisie zaś przypominają, ze stosunki polsko-perskie sięgają XVII wieku, kiedy to tworzono sojusze antytureckie. Z XVII wieku pochodzi również najstarszy zabytek polskiej części tego ormiańskiego cmentarza: grób posła Jana III Sobieskiego do perskiego szacha - Teodora Miranowicza, zmarlego w tym mieście w Boże Narodzenie 1686 roku. Nạ tym cmentarzu znajdują 
się też liczne mogily innych Polaków i żołnierzy armii Andersa, którzy wywędrowali w 1942 r. ze Związku Radzieckiego; Autorzy prezentują nawet zdjęcie jednej $\mathrm{z}$ cmentarnych płyt nagrobnych $\mathrm{z}$ polskim napisem: „† Nieznany katolik A.D. 1980" (s. 189). Szkoda, że nasi Autorzy wędrując po śladach armii Andersa zauważyli tylko te dwa polskie akcenty, bo jest ich zapewne więcej zarówno w Turcji, Syrii, Iraku i Iranie, jak i w innych państwach muzułmańskich i w Izraelu, gdyż one również są zapominane i zacierane, a była okazja, by je przypomnieć i ocalić.

Ostatnim wreszcie krajem dokumentowanym przez Autorów albumu w aspekcie wymierającego syryjskiego chrześcijaństwa jest Izrael (ss. 190208). Prezentowane w nim zdjęcia ukazują najpierw widok Jerozolimy i jej murów ze Zlotą Bramą, Bazylikę Świętego Grobu, na dachu której mieszkają w lepiankach z suszonej gliny ubodzy mnisi etiopscy, a w starej części miasta jakobicki klasztor św. Marka, stojący na miejscu domu matki św. Marka: to w nim pokazywana jest chrzcielnica, w której miala być ochrzczona Matka Najświętsza oraz jej ikony malowane przez św. Łukasza; tutaj też przechowywano przez jakiś czas odkryte nad Morzem Martwym zwoje z Qumran, tutaj wg innej tradycji miała się odbyć Ostatnia Wieczerza, a później Zmartwychwstały ukazał się apostołom. Obok Jerozolimy udokumentowano też zdjęciowo mury i ulice Betlejem oraz meczet Abrahama w Hebronie - miejsce ostatecznego spoczynku Abrahama, Sary i ich synów z żonami.

Należy się duża wdzięczność i uznanie Autorom omówionego wyżej albu$\mathrm{mu}$, że utrwalili w ciekawy sposób wizualnie i ocalili od zapomnienia ślady zatapianych w morzu islamu najstarszych wspólnot chrześcijańskich. $Z$ dużą korzyścią sięgną zapewne po ten „przewodnik” historycy Kościoła i badacze antyku chrześcijańskiego, którzy bez wyjeżdżania mają możność uświadomić sobie, ile zostało po 2000 lat $z$ kwitnących i tętniących życiem zakładanych często przez apostołów i ich uczniów wspólnot chrześcijańskich na Bliskim Wschodzie.

Ks. Stanisław Longosz - Lublin, KUL 